\title{
The Long Arm of the Law: Bringing International Drug Offenders to Justice in American Courts
}

\author{
Carl M. Williams \\ College of Criminal Justice, Sam Houston State University, Huntsville, TX, USA \\ Email: stdcmw44@shsu.edu \\ Received 16 February 2015; accepted 18 March 2015; published 24 March 2015 \\ Copyright (C) 2015 by author and Scientific Research Publishing Inc. \\ This work is licensed under the Creative Commons Attribution International License (CC BY). \\ http://creativecommons.org/licenses/by/4.0/ \\ (c) (i) Open Access
}

\section{Abstract}

The exportation of the US war on drugs to the international arena has relied on the deployment of various strategies designed to reduce the supply of illegal drugs to the American market, and to hold perpetrators in foreign countries accountable. This paper focuses on the use of extradition in facilitating the prosecution of foreign nationals, and, through a case study of Jamaica, examines some of the problems inherent in the process of arresting and transferring drug offenders from countries within Latin America and the Caribbean to "face justice" in American courts.

\section{Keywords}

War on Drugs, Extradition, International Narcotics Control Strategy Report (INSCR), Jamaican Drug Offenders, Irregular Rendition, Outsourcing Justice

\section{Introduction}

Few American "wars" have been as protracted or as vigorously fought as the war on drugs. The campaign against illicit drugs has its roots in the passage of the Harrison Act, which, from as early as 1914, reflected the concerns of the federal government about the unregulated consumption of opium and cocaine, arising from, among other things, "the unrestrained prescription of drugs by physicians" (Rasmussen \& Benson, 1994: p. 1). Buoyed by the policies of successive political administrations, the drug war has since endured to swell the capacity of the penal institutions, and with the total expenditure on narcotics control programs amounting to $\$ 2.5$ trillion within the last forty years (Suddath, 2009), has commanded a significant portion of the national budget. While American drug policy has been criticized in many quarters as a dismal failure (Ryan, 1998; Gray, 2001; Carpenter, 2003; Youngers, 2004), one of its more lasting manifestations has been the expansion to the frontiers 
of other countries which, wittingly or unwittingly, have become co-opted as allies in the US battle against drugs.

Friman (1996) categorizes the issues surrounding the exportation of American drug control policies and the consequential interaction with foreign countries as a form of "narco diplomacy". This perspective acknowledges that the war on drugs has grown to become a major pillar of US foreign policy, which rewards "allies" for support and threatens punitive action for countries perceived as not fully cooperative. In this milieu, the United States has managed to extend its reach beyond its own jurisdiction to bring perpetrators in foreign countries to justice in the United States, thereby truly globalizing the war on drugs. In the meantime, some of the countries that have been involved in the war are left to grapple with the legal dilemma that surrounds their "obligation" to surrender their nationals for trial in the American judicial system and how to politically respond to sentiments at home that are often opposed to this obligation.

Focusing primarily on Latin American and Caribbean countries, this paper examines various mechanisms that have been established for the arrest of alleged drug traffickers in their countries or other third countries for extradition to, and trial, in the United States. The case of Jamaica receives special attention for the purpose of analysis. The paper places the issue in context by examining some of the highlights of the drug war in the United States and selected Latin American and Caribbean countries. Next, the paper explores various legal mechanisms such as domestic statutes and case law both in the United States and cooperating countries, the bilateral agreements, and other legal and practical or informal arrangements surrounding the extradition of suspected drug traffickers to the United States. The discussion of these issues includes the socio-political concerns around the arrests in the extraditing countries - the nature of various political influences or pressures brought to bear on the extraditing countries-and the official and unofficial responses to these pressures. Finally, the paper examines viable options to extradition and charts the way forward for increased cooperation in the war on drugs.

\section{The Declaration of the War on Drugs}

The US war on drugs has its origins in the Harrison Act of 1914, which Rasmussen and Benson (1994: p. 2) describe as "America's first war on drugs". The act, they claim, was "conceived when the prevailing political view held that opiates and cocaine led to insanity and criminal activity. The conventional wisdom, obviously formulated by white males, held that cocaine degraded 'unfortunate women' and created 'the wild Negro' while opium was used by the 'devious Chinese”" (Rasmussen \& Benson, 1994: p. 2). The "war” jargon was not known to be associated with the problem then, but over the decades since the Harrison Act, government concerns over drug use and related maladies escalated to a level where it necessitated a "war" to combat illicit drugs. Nixon was the first American president to use the terminology "war on drugs" (Goode, 1997). In response to the recommendation by the Commission to decriminalize marijuana in 1972, President Nixon is reported to have remarked in a conversation with an official, "We need, and I use the word 'an all out war,' or all fronts...have to attack on all fronts" (Oval Office Tapes). From then on, the battle lines were drawn and the stage was set for President Reagan's unequivocally more war-like rhetoric.

"My generation will remember how America swung into action when we were attacked in World War II.

The war was not just fought by the fellows flying the planes or driving the tanks $\cdots$ [but also] at home by a mobilized nation $\cdots$ Well, now we're in another war for our freedom, and it's time for all of us to pull together again” (Alexander, 1990: p. 5).

Bagley (1988: p. 1) writes that the US Congress enthusiastically backed the president's initiative, by approving tougher national drug legislation, widening the US military's involvement in the war, supporting the administration's drive to intensify interdiction efforts along US borders, and expanding US-designed eradication, crop substitution, and law enforcement programs in foreign source and transit countries. He also notes that First Lady Nancy Reagan launched her own "Just Say No" campaign, flooding the American educational system and the public media with anti-drug messages. The war on drugs was on in earnest.

The US war on drugs has been waged from a prohibitionist perspective, which maintains a predominant focus on supply reduction as the primary strategy for winning the battle against illegal drugs (Williams, 2007). One of the most obvious implications of this approach has been its contribution to the explosive growth in the prison population which, as Mauer (2005) explains, moved from approximately 40,000 in 1980 to 450,000 in 2005. Scholars generally agree that the drug war has spawned many other harmful consequences, not the least of which include denial of due process, the erosion of privacy rights, the militarization of policing, and the less 
stringent application of rules concerning the introduction of illegally gathered evidence as proof of justice (Reiman, 2007). These are prohibitionist manifestations which indicate a privileging of supply reduction over demand reduction or drug enforcement over the treatment of drug addiction. Similarly, the exportation of the drug war can be understood within the context of the prohibitionist doctrine which is to take the fight to the source of the supply. In targeting the sources of supply, the US offers inducements to source and transit countries through a variety of programs, including crop eradication, crop substitution, mutual legal assistance treaties, and bilateral and multilateral enforcement operations. The presence of US law enforcement, military, and intelligence personnel posted overseas in drug source and transit countries to prosecute the war on drugs (Boggess, 1992) accomplishes an ideal that stops just short of deflecting the blame from the consumer to the producer and transit countries, and reinforcing the notion that the drug traffickers in these countries are really the ones to be held responsible for the ills associated with the trade in illicit drugs.

\section{Anti Drug Abuse Act (1986) and the Certification Process}

Even before the crack epidemic in the 1980s, the United States had traced a significant part of the roots of its drug problem outside of its own borders, mainly to the trafficking networks in Latin America and the Caribbean, but it was not until President Reagan's signing into law of the Anti Drug Abuse Act of 1986 that the international anti-drug campaign assumed the urgency with which it is characterized today.

The Anti Drug Abuse Act of 1986 has numerous provisions aimed at energizing the drug campaign in the homeland as well as taking the fight to the international arena. Of particular importanceis a stipulation that allows for the increase in taxes on products imported from countries that are not certified as cooperating with the US efforts to stop drug imports into the United States. Through the certification process, the President is required to certify, by March 1 of each year, major drug producing and transit countries as cooperating fully with US counter-drug measures. In the case of Latin America and the Caribbean, Carpenter (2003) describes this relationship as being characterized by a carrot and stick approach with more "sticks" than "carrots" in Washington's policy. Whenever the carrot of US aid dollars fails to secure cooperation from Latin American [and Caribbean] governments, Washington can resort to the stick (decertification). A country that fails to meet Washington's expectation could face decertification and the consequential sanctions of:

- Suspension of 50 percent of all US assistance (except humanitarian aid and international narcotics control aid) for the current fiscal year

- A requirement that US representatives in multilateral development banks such as the World Bank, the InterAmerican Development Bank and the International Monetary Fund (IMF) vote against loans to the offending country

- Denial of most favored nation (i.e., normal) tariff treatment to goods exported to the United States

- Imposition of duties of up to 50percent on exports to the United States and the curtailment of air transportation between the United States and the decertified country.

Lee (1988) reiterates that the US Congress has increasingly linked foreign aid to performance in narcotics control, and countries that are not seen to be taking adequate steps to control illicit drug production, trafficking, and money-laundering can lose certain specified economic and military assistance as well as preferences such as sugar quotas and Caribbean Initiative benefits.

According to Carpenter (2003), the mere threat of decertification gives the United States a potent diplomatic and political weapon against reluctant governments since the imposition of trade sanctions would have a devastating impact on nations with economies that depend heavily on access to the United States market. Latin American and Caribbean countries are left with virtually no option but to join as allies in the war on drugs and to conduct the fight according to terms dictated by the United States. These countries are burdened by their own share of drug related problems, but whatever ideas they may have about handling those problems have largely been supplanted by an enforcement agenda dictated by the United States. This includes the surrender of their nationals for prosecution in the American judicial system, an option, which, though unpalatable in many countries, is imposed on them as a necessary step toward victory in the war on drugs.

\section{The United Nations Convention}

Long before the concept of globalization was fully embraced, international drug traffickers had already become 
adept at networking in order to expand market share for their products, evade law enforcement, and launder and invest the proceeds of the illicit trade. Despite the existence of international treaties to promote cooperation in combating the international drug trade, no real effective counterbalance was achieved before 1988 when the United Nations put into force the Convention against Illicit Traffic in Narcotic Drugs and Psychotropic Substances. With over $75 \%$ of the countries of the world as signatories, the 1988 Convention, popularly known as the Vienna Convention, provides the most comprehensive set of measures against all forms of illegal drug production and trafficking, and related crimes, leading to the development of the strongest anti-trafficking measures that are generally accepted today. The countries that are signatories to the convention have been obliged to enact new legislation or modify existing legislation and policies to strengthen sanctions against drug related activities that were hitherto left out of their statutes. The most significant aspects of the convention however, are its mechanisms for bilateral, multilateral, and hemispheric cooperation, including but not limited to:

- limiting the demand for and consumption of illicit drugs

- preventing the diversion of precursor chemicals

- forfeiture and sharing of assets derived from the drug trade

- implementation of maritime (ship rider) agreements

- negotiation of Mutual Legal Assistance Treaties (MLAT)

- extradition of drug traffickers for trial in foreign jurisdictions

\section{International Narcotics Control Strategy Reports}

The 1988 United Nations Convention laid the foundation for the Government of the United States to introduce the International Narcotics Control Strategy Report (INCSR), an annual country-by-country report that assesses the efforts to attack all aspects of the international drug trade, including chemical control, and money laundering. Most importantly, the INCSR provides the basis for the US President to certify major drug producing and/or drug-transit countries regarding their full cooperation with the United States, or independent domestic action undertaken achieve full compliance with the goals and objectives established by the 1988 United Nations Convention. In other words, the INCSR provides a mechanism for the United States to rate the performance of countries around the world based on the level of their participation in the US war on drugs. Prepared annually by the US State Department's Bureau for International Narcotics and Law Enforcement Affairs, the INCSR is anxiously anticipated in countries around the world that are heavily reliant on US aid and are in danger of falling behind in the war on drugs for any reason, including inadequate law enforcement infrastructure or the socio-political capacity deal decisively with drug trafficking and related crimes. Many countries in Latin America and the Caribbean fall in this group and are acutely aware of the implications of US decertification for their struggling economies. Each year, the INCSR addresses the specific efforts of drug producing and transit countries, such as the extent of their cooperation with the United States in the enforcement of extradition treaties and the number of individuals extradited to be tried in the American courts.

\section{Extradition Treaties}

The extradition measures in the 1988 Convention provides a valuable mechanism for America's drug war in the international arena. Although the United States had already signed treaties with some countries before $1988^{1}$, it is believed that the awareness and commitments generated by the 1988 Convention were instrumental in stimulating new rounds of negotiations (Table 1 ) between the American government and foreign countries to strengthen existing extradition treaties and develop arrangements where none existed before. The increased activity was particularly noticeable in the countries identified as being responsible for supplying illegal drugs to America. Public Law 100 690, title IV, Sec. 4605, Nov. 18, 1988, 102 Stat. 4290, also known as the Extradition and Mutual Legal Assistance Treaties and Model Comprehensive Antidrug Laws, directed greater emphasis on the updating of extradition treaties and on negotiating mutual legal assistance treaties with major drug producing and drug-transit countries. The law also called for the development of model treaties and anti-narcotics legislation. Between 1988 and 1996, the United States completed negotiations and signed extradition treaties with more than 11 Latin American and Caribbean countries.

${ }^{1}$ According to 18 USC Section 3181Sec. 318 The United States [was] a party to the Multilateral Convention on Extradition signed at Montevideo on Dec. 26, 1933, and entered into force for the United States on Jan. 25, 1935. 
Table 1. Latin American and Caribbean countries with Bilateral ExTradition Treaties with the United States.

\begin{tabular}{|c|c|c|}
\hline Countries & Year Signed & Year in Effect \\
\hline Antigua and Barbuda & 1996 & 1999 \\
\hline Argentina & 1997 & 2000 \\
\hline Bahamas & 1990 & 1994 \\
\hline Barbados & 1996 & 2000 \\
\hline Belize & 2000 & 2001 \\
\hline Bolivia & 1995 & 1996 \\
\hline Colombia & 1979 & 1982 \\
\hline Costa Rica & 1982 & 1991 \\
\hline Cuba & 1904 & 1905 \\
\hline Dominica & 1996 & 2000 \\
\hline Dominican Republic & 1909 & 1910 \\
\hline Grenada & 1996 & 1999 \\
\hline Guatemala & 1903 & 1903 \\
\hline Haiti & 1904 & 1905 \\
\hline Jamaica & 1983 & 1991 \\
\hline Mexico & 1978 & 1980 \\
\hline Panama & 1904 & 1905 \\
\hline Paraguay & 1998 & 2001 \\
\hline Peru & 2001 & 2003 \\
\hline St. Kitts and Nevis & 1996 & 2000 \\
\hline St. Lucia & 1996 & 2000 \\
\hline St. Vincent and the Grenadines & 1996 & 2000 \\
\hline Trinidad and Tobago & 1996 & 1999 \\
\hline Venezuela & 1922 & 1923 \\
\hline
\end{tabular}

Source: Public Law 100-690, title IV, Sec. 4605, Nov. 18, 1988, 102 Stat. 4290.

\section{General Requirements of Extradition Treaties}

According to Public Law 99-93, title I, Sec. 133, Aug. 16, 1985, 99 Stat. 420, "The Secretary of State, [of the United States] with the assistance of the National Drug Enforcement Policy Board, shall increase United States efforts to negotiate updated extradition treaties relating to narcotics offenses with each major drug-producing country, particularly those in Latin America.” Federal statute, 22 USCS, Section 2651 obliges the Secretary of State to make the extradition of drug traffickers a priority issue of United States missions in major illicit drug producing or transit countries. The law specifies that the diplomatic mission in each country should ensure the completion and effective implementation of extradition treaties to facilitate the extradition and trial in the United States of individuals indicted by US prosecutors.

In general, extradition proceedings for fugitives to be sent from a foreign country for trial in the United States begin with a request from the Department of Justice to the Secretary of State. Providing that there is an extradition treaty in force with the foreign country, the Secretary of State through the US diplomatic mission in the foreign country relays the request to the equivalent party in the country. If the foreign government acquiesces, the equivalent party, the Ministry of Foreign affairs in the case of Jamaica, passes the request on to the law enforcement policy directorate (the Ministry of National Security in Jamaica), which turns the request over to the local law enforcement agency. As observed by Nadelmann (1993), US law enforcement officials are increasing- 
ly involved in orchestrating and even managing the apprehension of fugitives abroad, often providing foreign authorities with the tactical intelligence needed to locate and arrest fugitives on their territory. The fugitives, when arrested, face extradition hearings in the local courts where they may either waive their rights to a hearing, or exhaust their legal options. Once the courts are satisfied that the fugitives have a case to answer in the United States, they may order the fugitives extradited.

\section{Factors Affecting the Decision to Extradite}

Notwithstanding the existence of signed extradition treaties with the United States, some countries tend, for varying reasons, to resist the dispatch of their nationals to face the US justice system. McPherson (1998) attributes this reluctance to a distrust of foreign proceedings, either because requesting states may not ensure due process or because of possible prejudice against foreigners. He argues that nationalistic concerns about the propriety of handing nationals over to a foreign state also underlie this reluctance (p. 20). Commenting on Mexico's attitude to extradition in the past, Spector (1998: p. 5) notes that Mexico's extradition law, combined with a reluctance to acknowledge the magnitude of international drug trafficking, effectively prevented the extradition of any Mexican national to any foreign country for violation of drug laws. Between 1984 and 1996, the United States submitted 151 extradition requests to Mexico, of which 39 were successful, but none of the 39 involved any Mexican citizen (Spector, 1998: pp. 12-13). Mexico's resistance continued through the 1990s and well into the new millennium before any progress was seen. There was a significant shift 2007 when the extradition of four drug traffickers to the United States was hailed by then Attorney General Alberto Gonzales as unprecedented and described by the US Ambassador as "a monumental moment in the two nations' battle with the vicious drug traffickers and criminals who threaten our very way of life” (Roig-Franzia, 2007). By the end of 2008, the new US Attorney General, Michael Mukasey, heaped praise on Mexico for the courageous action of its government in extraditing 10 defendants for major drug offenses or other serious federal felonies, and for showing the unrelenting commitment of Mexican President Calderon to break the power of the Mexican drug cartels (Federal Bureau of Investigation, 2008).

Colombia's reluctance on the other hand, was based initially on a combination of legal and constitutional concerns, as well as vigorous opposition from the drug cartels. Bagley's (1988) explains that Colombia's policymakers first refused to extradite, then yielded to US pressures, but subsequently procrastinated in the face of a withering campaign of mafia violence and intimidation, and ultimately backed away from further compliance while shrouding their retreat in a fog of legal-constitutional arguments. The 1998 INCSR mentions Colombia's failure up to 1996 to enforce the United States-Colombia extradition treaty and notes that the failure was based on internal legislative and constitutional problems. Interestingly, the \$2 billion Plan Colombia aid package from the US to the Government of Colombia at the turn of the century suggested a justice sector reform that was geared at ensuring punishment of criminals and extradition within the context of Colombian law (Bibes, 2001: p. 254). In the subsequent years (2002-2006), dramatic improvements were marked by Colombia's extradition of 417 criminal suspects to the United States with 102 extraditions occurring in 2006 alone (INCSR, 2007). Writing in the Miami Herald, Dudley (2009) highlights criticisms which suggest that the extradition of almost 900 suspects between 2002 and 2009 was due to the efforts of Colombia's president Alvaro Uribe to "curry favor" with Washington.

In a dramatic turn of events, the Supreme Court of Colombia issued a ruling in February 2009 that some observers have regarded as a major setback for the war on drugs. According to the Miami Herald (March 6, 2009), in February 2009 the Colombian Supreme Court blocked the extraditions of a number of FARC leaders for their alleged involvement in the kidnapping of several persons, including 3 Americans, ruling that the United States had no jurisdiction over Colombians in certain crimes committed in Colombia, including "taking hostages". This, the newspaper surmises, marked a major shift in Colombian extradition policy and puts both governments [Colombia and the United States] in a quandary.

There have been equally noteworthy occurrences in the Caribbean. For example, the US was forced to await the determinations of the legal system of St. Kitts and Nevis and the United Kingdom Privy Council for over four years (1996 to 2000) for the extradition of fugitive Charles "Little Nut" Miller, a former Shower Posse gangster who was indicted in the on drug trafficking and murder charges in New York and Florida. Miller, a financier of political campaigns in St. Kitts, was allowed by the authorities in the country to remain free while he litigated his case, and in the interim was accused of threatening American students studying in the island, 
much to the dismay of the United States (Fitzgerald, 2002).

In Jamaica, many prominent attorneys and allied interests have strongly protested the extradition of citizens to the United States, asserting that they will not be guaranteed fair trials. A special report in the Jamaica Gleaner of April 4, 2004 stated that many lawyers in private practice are strongly of the view that the Jamaica-United States extradition treaty is weighted against Jamaican extradition accused and should be re-negotiated. These sentiments foreshadowed the much heralded case surrounding the extradition of Christopher "Dudus" Coke which unfolded in 2009-2010. Coke, the alleged leader of the Shower Posse, was indicted by a New York grand jury on drugs and firearm trafficking charges and an extradition request followed to secure his presence for trial in the United States (Mulvey, 2009). In a departure from conventional practice, the Jamaican government refused for 9 months to comply with the request on grounds that the evidence in the case was weak and unlawfully obtained (INCSR, 2010). Addressing the Jamaican Parliament, the Prime Minister insisted that his defense of Coke's constitutional rights as a citizen of Jamaica was not politically contrived but was guided by the concepts of fairness and justice (Jamaica Observer, 2010). However, given Coke's considerable influence in the criminal underworld and his close connections to the governing Jamaica Labour Party, popular opinion suggested that the government's legal objections werepredicated on apprehensionsof a violent backlash and political fallout among Labour party supporters in communities where he held sway. As the government came under tremendous pressure from the United States as well as local interest groups which feared US economic and diplomatic sanctions, the Prime Minister relented and Coke was eventually extradited.

\section{Justice: By Any Means Necessary}

Generally, the issue of extradition is a thorny one. The movement of individuals from one jurisdiction to face justice in another is fraught with legal, political, and practical difficulties, which are not always easily resolved despite the existence of treaties or even the good intentions of nations. In the past, the United States has overcome some of the obstacles to formal extradition through resort to "irregular rendition", an option that is itself shrouded in legal and political controversy. First coined by John Bassett Moore in his classic 1891 treatise on extradition (Nadelmann, 1993: p. 437), the term "irregular rendition" refers to a little known process involving the forceful abduction of an individual from one country by agents of another country, outside of the parameters of extradition treaties, and principally without the knowledge or consent of the former (Laflin, 2000). According to Nadelmann (2003), irregular rendition has also acquired names such as "de facto extradition", "informal expulsion", and even "extradition Mexican-style" in recognition of the long-standing "arrangement" by which fugitives are pushed over the border by Mexican police into the hands of US law enforcement agents. The process entails the employment of various ruses, both unilaterally and in cooperation with foreign operatives to lure fugitives to the United States (where sealed indictments await them) or to other countries from which their rendition can be more readily arranged, or into international waters where they can be seized and returned to US territory (Nadelmann, 1993).

Perhaps the best known example of irregular rendition is that which became the subject of the famous Supreme Court case of United States v. Alvarez-Machain, 504 US 655 (1992). In this case, Dr. Alvarez-Machain, a citizen of Mexico was abducted from his office in Mexico in 1990 on the basis of a plan approved by the United States Drug Enforcement Administration (DEA). Dr. Alvarez-Machain was subsequently forced aboard a private aircraft flown to Texas where he was arrested for his part in the kidnapping and murder of a DEA agent. Upon concluding that DEA agents were involved in the abduction, the US District Court for the Central District of California dismissed the indictment on the premise that it violated the extradition treaty between the United States and Mexico, and ordered Dr. Alvarez-Machian repatriated. On appeal, the United States Court of Appeals for the Ninth Circuit affirmed the ruling of the District Court. However, in a 6-3 decision, the US Supreme Court reversed the Court of Appeals holding that to infer from the treaty that it prohibited all means of gaining the presence of an individual outside of its terms went beyond established precedent and practice. In arriving at the decision, the Court rejected the argument that such abductions undermine the usefulness of extradition treaties, and it refused to read general principles of international law weighing against such abductions into the Mexican extradition treaty in particular. The Court held that Dr. Alvarez-Machain's abduction did not prohibit his trial in a court in the United States. Essentially, the court's decision affirmed that there was nothing unlawful about the kidnapping of individuals in foreign jurisdictions to face justice in American courts.

The Alvarez-Machain decision rested on foundations laid more than a hundred years earlier by the Supreme 
Court's decision in Ker v. Illinois, 199 US 436 (1886), which has been sine qua non in similar cases, prior and subsequent to Alvarez-Machain. The Court held that a fugitive kidnapped from abroad could not claim any violation of the Constitution, laws, or treaties of the United States. The incident culminating in this decision involved a Pinkerton detective commissioned by US government in 1883 to collect a larcenist, Frederick Ker, who had fled to Peru. On arrival in Lima, Peru, the detective found no one to accommodate his request due to the recent occupation of Lima by Chilean military forces. Instead of returning home empty-handed, the detective kidnapped Ker and brought him back to the United States where he was tried and convicted. Ker has been interpreted to mean that a prisoner kidnapped in a foreign country and brought by force against his will within the jurisdiction of the State whose law he has violated, with no reference to an extradition treaty [whether one existed or not], and no proceeding or attempt to proceed under the treaty, can get no relief, because he has no established rights under the Constitution, or laws, or treaties of the United States.

In the subsequent case of Frisbie v. Collins, 342 US 519 (1952), a defendant was tried and convicted in Michigan after being abducted in Chicago by law enforcement authorities from Michigan. On appeal, the Supreme Court applied its decision in Ker, upholding the conviction over challenges based on the Due Process Clause of the Fourth Amendment and federal kidnapping statutes. One of the enduring legacies of the decision has been the establishment of the Ker-Frisbie doctrine, which holds generally that US Courts may exercise proper jurisdiction and criminal defendants may be prosecuted regardless of whether their presence has been procured by means of a forcible abduction.

\section{Sanctioned Kidnapping: The Application of Legal Precedent}

During the 1980s-1990s, the Ker-Frisbie doctrine provided carte blanche justification for kidnappings in other countries, including Panama and Jamaica. For instance, Gilboa (1995) recalls the American military invasion of Panama in 1989 to capture then Panamanian Head of State, General Manuel Noriega, who was subsequently extradited to the United States to answer drug trafficking charges. In a case of lesser significance, Norris Barnes, a Jamaican businessman who was indicted for drug offenses in the United States, was in 1992 enticed onto a yacht by DEA agents who kidnapped and took him out of Jamaica. Barnes was put on trial in the United States where he spent two years in prison (Williams, 2004). On his return to Jamaica, Barnes brought action in the Jamaican courts against two DEA agents and their Jamaican collaborator for their role in the kidnapping. There have been at least two other incidents on record in Jamaica in which attempts were made to remove (by force or subterfuge) fugitives from Jamaica and take them to the United States for trial (Williams, 2004). The first of these two cases involved an American bondsman whose attempt to kidnap a Guyanese suspect from Jamaica was thwarted by alert Jamaican immigration officers, while the second involved an American private investigator who, after coming under suspicion, was forced to abandon his attempt to kidnap a Jamaican who was previously indicted in Colorado (Williams, 2004).

Yet another well known Jamaican case involved the Shower Posse member and alleged drug trafficker, Richard "Storyteller" Morrison, who in 1991, was inadvertently extradited to the United States while an appeal was pending in the Jamaican Court of Appeal. The inadvertence, according to the special report in the Jamaican Gleaner (April 8, 2004), was due to an administrative error in the registry of the Jamaican Court of Appeal. Jamaica requested that Morrison be returned, but the United States, consistent with the principles of the Ker-Frisbie Doctrine, refused (Rowe, 2009). To complicate matters, it was reported that Morrison had been tried in the United States for offenses other than those for which he was extradited, which was in contravention with Article XIV of the Extradition Treaty. The Jamaican government protested the breach and sought assurances from the United States that there would not be a recurrence. The incident triggered a considerable amount of discussion in Jamaica including an explanation to the nation by the Minister of National Security and Justice, and a call for negotiations to amend the extradition treaty with the United States. One of the lasting legacies of this incident has been the guarded suspicion of many Jamaicans of matters related to extradition to the United States (Williams, 2004).

Notwithstanding public misgivings, Jamaica remained a strong partner of the United States, extraditing an average of 10 fugitives each year between 2000 and 2008, there by justifying the commendation of the Bureau of International Narcotics and Law Enforcement Affairs which, in its 2003 INCSR, declared: "Nine fugitives were extradited to the United States during the year [2002]. Jamaican authorities are receptive to and cooperative with US requests for extradition, and are working with US authorities to accelerate the extradition process.” 
However, these complimentary tones stand in sharp contrast to the language of the 2010 report, when, in response to Jamaica's delay in handling the extradition request for Christopher "Dudus" Coke, its commitment to law enforcement cooperation with the United States was seriously called into question (INCSR, 2010).

\section{Outsourcing Justice: The Jamaican Rationale}

Several years of campaigning against the illicit drug trade had drawn mixed reviews for Jamaica. Following numerous successful drug seizure operations between 2000 and 2003, Jamaica's efforts in the war on drugs was summed up thus: "The Government of Jamaica has taken steps to protect Jamaica against drug trafficking and other organized crime but needs to intensify and focus its law enforcement efforts and enhance international cooperation in order to disrupt the trafficking of large amounts of cocaine through Jamaica and its territorial waters” (INCSR, 2004). Then, as though directing Jamaica's drug enforcement agenda, the INCSR proceeded to outline areas in which actions were needed, including arresting and prosecuting major drug traffickers operating in Jamaica, dismantling drug-trafficking organizations, and increasing drug seizures and eradication. However, drug enforcement in Jamaica was not nearly as straightforward as it was made out to be. Jamaica's drug trafficking networks had been fairly well entrenched and anti-narcotics endeavors were consistently bedeviled by numerous legal, political, and systemic impediments.

Prior to the release of the 2004 INCSR, the Jamaican Narcotics Police, assisted by the DEA and other local and international law enforcement and intelligence agencies had already embarked on intensive investigations of top level local and regional drug traffickers with a view to arrest and prosecute them, seize their assets, and dismantle their networks. Previous efforts to arrest such high level traffickers were not always successful due a number of reasons, not the least of which was complicity at varying levels of the criminal justice system. Several researchers (for example, Johnson \& Soeters, 2008; Harriott, 2003) linked the ineffectiveness of some police officers in fighting the drug trafficking to their own involvement in the illicit trade. Furthermore, drug enforcement endeavors were hamstrung by what some observers label the lack of political will (Jones, 2002; Johnson \& Soeters, 2008). The 2010 INCSR exhorted the Jamaican government to "demonstrate its political will to address corruption by successfully investigating, prosecuting and convicting corrupt officials at all levels of government service and by the timely extradition of fugitives in accordance with the provisions of the bilateral extradition treaty, without regard to political influence or party affiliation.”

To further complicate the job of Jamaican law enforcement agents, several of the major drug traffickers had quite generously taken on many of the welfare needs of their communities (Sives, 2002) and had become so popular that law enforcement authorities could look forward to very little support from residents in building cases against them. For instance, there were occasions on which police operations against drug traffickers were thwarted by ordinary citizens who stood to derive benefits from the drug trade. In the rare event that the police managed to apprehend and successfully prosecute high level offenders in major drug cases, there would be little certainty under the Jamaican drug laws that trials would be swift or that the punishment would be commensurate with the crime. Jamaican Narcotics investigators reveal that drug cases involving major offenders can be dragged out for up to five years before finaldisposal in the local courts. Furthermore, the Dangerous Drugs Act (1948) has provisions for drug cases to be tried by a magistrate court, which can impose a maximum sentence of 5 years, as well as a circuit court, which can impose a maximum sentence of 35 years, but the practice in Jamaica has historically been for drug offenders, no matter how significant, to be tried in the magistrate court. This means that high level drug offenders convicted under Jamaican law could look forward to relatively short stints in prison. At any rate, it is quite difficult to prove cases against high level drug offenders because they generally keep their hands "clean", meaning that they are seldom found in direct contact with illegal drugs, preferring to use their lower level cronies to do their "dirty work". The lack of effective legal mechanisms like the American styled RICO ${ }^{2}$ statutes which allow prosecutors to link numerous members of crime syndicates in a single conspiracy makes it even less likely that these offenders will be brought to justice in Jamaica.

The numerous hurdles encountered in the arrest and prosecutions of major drug offenders in Jamaica have rendered the whole process inefficient and ineffective. Therefore, the extradition of these offenders for trial in foreign jurisdictions presents a workable alternative for many who are eager to see these criminals brought to justice. In this regard, extradition represents a kind of "justice outsourcing" that relieves extraditing countries of most of the burdens of putting drug offenders on trial and proving charges against them. Outsourcing, the prac-

\footnotetext{
${ }^{2}$ Racketeer Influenced Corrupt Organization Statutes.
} 
tice of charging external service providers with the task of performing in-house activities (Bolumle et al., 2007) is increasingly an essential way of business in the globalized world, and it seems a practical and convenient method of dispensing justice in transnational drug cases, which are equally global in nature and scope. The concept, "outsourcing justice", has seen prior use in Criminology and Criminal Justice in connection with cases in which judges send parties to mediation (Keddie, 2006). As used here, however, justice outsourcing alludes to the willingness of security officials in some countries to process criminal prosecutions in another country in order to secure convictions and/or stiffer penalties. This willingness is sometimes reflective of local security concerns in countries where the successful prosecution of high level criminal offenders are often hindered by small population in which victim, offender, and adjudicator may all be known to each other, or where jurors may be reluctant to convict out of fear of reprisals. Under such circumstances, security officials may be more amenable to extradition as a means of securing justice.

Justice outsourcing in narcotics cases is not unique to Caribbean and Latin American jurisdictions. James Sheptycki makes reference to a Dutch police official who, in a taped interview in 1995, rationalized "justice outsourcing" in drug cases thus:

"If we arrest a drug dealer here in the Netherlands he will be given a penalty of a maximum of six months in prison. If we arrest him in Germany he will get a maximum of six years. We arrest them in Germany. It is better I think" (Sheptycki, 1996: p. 61).

One of the chief goals of outsourcing is cost effectiveness (Collins et al., 1997) but outsourcing is not without its hidden costs (Barthelemy, 2003). In the world of commerce, its hidden costs may include issues such as increased unemployment at home but in extradition matters, they may range from social and political fallouts to serious injury of national pride.

\section{Extradition of Jamaican Drug Offenders}

Following a series of successful intelligence-driven multi-lateral anti-drug operations in Jamaica, Colombia, and the Bahamas in 2004, scores of high level drug traffickers wanted by the local police and the DEA were arrested, and a large portion of their assets seized, and actions commenced to dismantle their criminal empires (Figueira, 2004). Several other known drug traffickers went underground, according to Jamaican Immigration records and intelligence reports, fleeing to foreign countries including Cuba where they felt they would be safe from arrest and possible extradition. The Jamaican operations netted some of the biggest names in the international drug trade including Leebert Ramcharan, Norris “Dedo" Nembhard, and Robroy "Spy” Williams (Figueira, 2004) and elicited lofty praise from the US Government (INCSR, 2005). The United States proceeded through the usual channels with requests for their extradition.

Shortly after the arrests, President George W. Bush, in accordance with the Foreign Narcotics Kingpin Designation Act (Kingpin Act), 21 U.S.C. Section 1901-1908, 8 U.S.C Section1182, designated Ramcharan and Nembhard narcotics kingpins ${ }^{3}$ (INCSR, 2005) triggering a fresh round of debate in Jamaica. The Kingpin Act defines a kingpin as a significant narcotics trafficker and it blocks all property and interests in property in the US that is owned or controlled by such traffickers. The Act also blocks the property interests of anyone found to be offering material, financial, or technological support to the narcotics trafficking activities of a person designated (Office of Foreign Assets Control, 1995). While DEA officials viewed the kingpin designations with optimism, reasoning that it would influence local courts to quickly wrap-up the extradition hearings, defense teams sought to have the cases dismissed by the local courts. Their principal argument was that the kingpin designation would prejudice the process against their clients and as such, they would most certainly not be guaranteed a fair trial in the United States (Gayle, 2007). As the cases went to the Jamaican Supreme Court, the lawyers' arguments were consistent with earlier arguments presented to a Circuit Court in the Bahamas that the kingpin label on Samuel Knowles, a Bahamian national fighting his extradition to the United States would not assure him a fair trial in the United States (Swain, 2004). Following protracted legal battles in the local courts and the United Kingdom Privy Council, Jamaica's highest court of appeal, the extradition orders were signed and the suspects flown out of Jamaica to face justice in the United States.

Having been brought before the federal courts in Florida, the trials of the Jamaican defendants seemed almost perfunctory. Initially, they tried to hold out by asserting their innocence, but sentences of up to 35 years in pris-

${ }^{3}$ The Kingpin Act defines a kingpin as a significant narcotics trafficker. 
on meted out at the completion of the first two trials became an ominous foreshadow of what awaited the remaining six defendants. Consequently, like many of the of previous international defendants tried by the US courts, the remaining Jamaican defendants plea bargained, thus closing another chapter in the US war on drugs and demonstrating the extraordinary reach of the American justice system. The more recent arrest and extradition of Christopher Coke, even after the strenuous and lengthy legal and diplomatic protestations by the Jamaican Government, proves that the US justice system, like the Canadian Mounties, "will always get their man”.

\section{The Future of Extradition in the War on Drugs}

The Jamaican experience constitutes a small but important part of the larger discourse regarding the appropriateness of extradition as a tool in fighting the US war on drugs and other transnational organized crime. The larger discourse continues to evoke emotional responses from both sides of the divide-those in favor of and those against extradition. Often when the topic is raised, it is difficult to avoid the questions of fairness, ethics, sovereignty (Gilboa, 1995; Zaid, 1997), and political and jurisdictional complexities (Addis, 2009) posed by those who are concerned about the appropriateness of extradition as a means of waging the war on drugs. For example, extraditions from Jamaica have elicited cogent questions from politicians, some members of the Jamaican bar, and radio talk shows regarding the fairness of the process (Nicholson, 2007). Conversely, the proponents of extradition deem it a panacea against domestic inertia when confronting the transnational drug trade and they are equally strident in their calls for increased cooperation and more stringent actions by the United States to persuade reluctant partners to cooperate. Spector (1998: p. 23), for instance, linked the prospects of an improvement in Mexico's war against the drug cartels to extradition to the United States, arguing that the cartels' control will diminish and their extravagant lifestyles will end as soon as Mexico begins to extradite drug traffickers wanted by the United States. There have since been dramatic improvements in extraditions of narcotics traffickers from Mexico to the United States (Roig-Franzia, 2007). However, the outbreak of drug related violence that claimed the lives of more than 7000 Mexicans in the border town of Juarez in just over a year, and triggered a steady stream of exiles north of the border to El Paso (Padgett, 2009), has raised fresh questions as to the effectiveness of extradition as a tool in the war on drugs. It is perhaps too early to provide definitive answers.

As the debate continues, a 2009 decision by the Colombian Supreme Court to block the extradition of several individuals indicted to face kidnapping charges in the United States evoked emotionally charged responses from observers on both sides of the issue (Dudley, 2009). In the aftermath of the ruling, Rafael Nieto, a former Vice Minister of Justice in Colombia said:

"The risk I see with these decisions is that they endanger extradition, which has been vital to the fight against drug trafficking. This is a restrictive interpretation [of the extradition law] that I think favors delinquents” (Dudley, 2009: A7).

Admitting that he was confused by the Court's ruling, US Ambassador to Colombia, William Brownfield's reaction was that although the United States accepted these decisions, the court had reached a different conclusion in several instances over the past year in cases with similar sets of facts (Dudley, 2009). The counter argument from Alfonso Gómez Méndez, a former Attorney General in a previous Colombian administration was, "Extradition needs to return to its original function, [because it] had become so disfigured and it had become a political tool, especially in this government” (Dudley, 2009: A7).

Other scholars, such as McPherson (1998) and McConville (2000), tend to take a more middle-of-the-road approach, advocating instead, the International Criminal Court of Justice (ICC) to overcome perceived unfairness and mitigate feelings of national pride that are often an obstacle to extradition. McConville (2000) believes that sending an accused to the international court would not constitute extradition since the accused would not be delivered to a sovereign state. However, there are no guarantees that the same factors influencing the reluctance of countries to surrender their citizens to the United States would not also beset the efforts of the international court. Neither can there be any certainty that requesting countries would acquiesce to an expanded role for the ICC. McConville's (2000: p. 76) suggestion that "international drug trafficking is a problem in need of a solution, while the ICC is a solution in need of a problem," ignores some of the more practical and jurisdictional implications, as well as the nationalistic posturing that inevitably arises in many countries.

First of all, powerful states that are affected by transnational organized crime including drug trafficking and 
related crimes perpetrated by criminals in lesser developed countries are unlikely to surrender the jurisdictional claims derived from the existing treaty arrangements by ceding the dispensing of justice to an international court. For instance, it is unlikely that the United States would find any advantage in jurisdictional expansion of the ICC that would empower the court to sit somewhere in Europe and adjudicate cases involving drug traffickers from the Caribbean and Latin America who are accused of flooding the streets of Miami with cocaine. After all, this position would be entirely inconsistent with the spirit and principles of the Monroe doctrine, which has long sought to establish separate spheres of influence for the United States and Europe. At any rate, the United States' proven record of indifference towards the ICC does not inspire the confidence of this proposal (Quigley, 2009). The remarks of Jamison S. Borek, a US State Department official during the Clinton Administration, sum up America's attitude towards the international court, and all but foreclose the argument:

"The crimes of terrorism and drug crimes present particular problems of investigation and prosecution which the court would inevitably be ill-equipped to address... The investigation of these crimes requires major police and technical resources which the court will not have. The prosecution of these crimes, moreover, does not occur in isolation, but rather as part of an overall investigative and prosecutorial strategy [with the goal to] reach the key figures at the top. These cases are thus essentially tied to national investigations” (McPherson, 1998: p. 44).

In 2005, the United States was involved in a dispute with the international court that led to its eventual withdrawal from the court's jurisdiction. The dispute was a response to the court's decisions in two cases arising from the failure of American law enforcement officers to observe consular access for arrested foreign nationals (Quigley, 2009). America's withdrawal from the ICC (Quigley, 2009), combined with long running sentiments against the court (McPherson, 1998), have conceivably wiped out any realistic hopes of the ICC emerging as the tribunal of choice to arbitrate international drug trafficking cases in the near future.

Even if the ICC is embraced by the United States, its prosecution of international drug cases would not likely resolve the more salient political and jurisdictional arguments currently surrounding the extradition issue. The removal of suspects from their countries to the location of the international court would still be tantamount to extradition, except perhaps in name. Gupta (2000) notes, for instance, that although the ICC is clearly different from a sovereign state, state practice regarding the existing international criminal tribunals reveal that extradition laws will be applied to the ICC, perhaps with even stronger force. This, Gupta (2000) reasons, would pose unique opportunities for suspects to avoid the reach of the court by finding safe harbors in states that have not ratified the treaty, or in common law states that have evidence requirements for arrest that are more stringent than the ICC standards, thereby allowing the suspects to escape.

Additionally, it would be no less difficult to persuade reluctant countries, many of which are still of the philosophical view that extradition of their citizens for trial in a foreign jurisdiction constitutes a compromise of their sovereignty (Henley, 2006), that the international court is any different from a court in the United States. The preferred option for many of these countries is to prosecute their citizens at home, but as McConville (2000) argues, pointing to Latin American and the Caribbean countries as examples, drug related corruption and the fear of violent repercussions may prevent successful prosecution. Another concern about home trials in some countries is the inadequate legal and judicial capacity to try drug traffickers for international crimes. As an example, McConville (2000) highlights the plight of Haiti, where severe poverty and a dysfunctional criminal justice system make the country an ideal target and staging area for the large and sophisticated international drug trafficking syndicates. While the situation is far less dire in other Caribbean states, it is not inconceivable that the international drug syndicates with their vast resources could easily overwhelm the fragile criminal justice infrastructure in many of these states.

\section{Conclusions}

There is little doubt that the present arrangements for extradition of drug traffickers from one country to another will remain some of the more controversial elements of the war on drugs. Significant overhauls will therefore be required to make extraditions acceptable to the vast majority of people who now see it as inherently unjust or as a coercive tool of powerful countries to use against the weak. The first step must be to raise the awareness of governments and people in extraditing states as to the real ravages of the international drug trade for producer, transit, and consumer countries. Such an endeavor will necessitate programs to reach a wide cross-section of the 
populations, particularly those in the drug source and transit countries, to which extradition requests are most often directed. Programs should also include capacity building for law enforcement and judicial institutions to generate credible responses to the incursion of the illicit drug trade. Where anti-narcotics laws are weak, their strengthening should be encouraged, and extradition treaties introduced where none exists, or renegotiated where necessary to avoid ambiguities or prevent legal technicalities popping up in the middle of a case and also to prevent fugitives from seeking refuge in countries without treaties. The United States should join forces with other developed countries to give leadership to this process and material support to the initiatives.

The next step should involve the removal where practicable of all semblances of coercion and subterfuge from the process of bringing suspects to trial in a foreign jurisdiction. Methods like irregular rendition or kidnapping should find no acceptance in the criminal justice practices of modern nations. Methods such as these create legal and ethical conundrums that suggest the breaking of the law to enforce the law and foster disrespect for sovereignty. The question remains however, as to what should be done with reluctant suspects and states that shelter them from the reach of the states whose laws they violate. This is a challenge for academe. From here on, the focus of academe should be the quest for workable solutions to the current problems surrounding extradition that will be acceptable to the international community. Without attention to this important issue, extradition as a tool in the war on drugs will remain shrouded in controversy and mistrust of the type that defeats the ends of justice.

\section{References}

Addis, A. (2009). Imagining the International Community: The Constitutive Dimension of Universal Jurisdiction. Human Rights Quarterly, 31, 29-162. http://dx.doi.org/10.1353/hrq.0.0067

Alexander, B. K. (1990). Peaceful Measures: Canada's Way Out of the “War on Drugs”. Toronto: University of Toronto.

Bagley, M. B. (1988). US Foreign Policy and the War on Drugs: Analysis of a Policy Failure. Journal of Interamerican Studies and World Affairs, 30, 189-212.

Barthelemy, J. (2003). The Seven Deadly Sins of Outsourcing. Academy of Management Executive, 17, 87-98. http://dx.doi.org/10.5465/AME.2003.10025203

Bibes, P. (2001). Transnational Organized Crime and Terrorism: Colombia, a Case Study. Journal of Contemporary Criminal Justice, 17, 243-258. http://dx.doi.org/10.1177/1043986201017003004

Bolumle, Y. A., Frankel, R., \& Naslund, D. (2007). Developing a Theoretical Framework for Logistics Outsourcing. Transportation Journal, 46, 34-54.

Carpenter, T. G. (2003). Bad Neighbor Policy: Washington's Futile War on Drugs in Latin. America. New York, NY: Palgrave MacMillan.

Collins, R., Belcher, K., \& Pires, S. (1997). Outsourcing in the Automotive Industry: From JIT to Modular Consortia. European Management Journal, 15, 498-508.

Dudley, S. (2009). Colombia Extradition Rulings Stoke Worry in U.S. The Miami Herald, A1, A7.

Federal Bureau of Investigation, San Diego (2008). Ten Major Drug Defendants Extradited from Mexico to the United States. http://sandiego.fbi.gov/dojpressrel/pressrel08/sd_123108.htm

Figueira, D. (2004). Cocaine and Heroin Trafficking in the Caribbean: The Case of Trinidad and Tobago, Jamaica, and Guyana. Bloomington, IN: I Universe.

Fitzgerald, M. (2000). Ombudsmanship, “Little Nut”-Style. Editor \& Publisher, 133, 10.

Friman, R. (1996). Narco Diplomacy: Exporting the US War on Drugs. New York: Cornell University Press.

Gayle, B. (2007). Kingpin Loses Appeal. Jamaica Gleaner. www.jamaica-gleaner.com/gleaner/20070317/lead/lead1.html

Gilboa, E. (1995). The Panama Invasion Revisited: Use of Force in a Cold War Era. Political Science Quarterly, 110, 539562. http://dx.doi.org/10.2307/2151883

Goode, E. (1997). Between Politics and Reason: The Drug Legalization Debate. New York: St. Martin's.

Gray, J. P. (2001). Why Our Drug Laws Have Failed and What We Can Do about It: A Judicial Indictment of the War on Drugs. Philadelphia, PA: Temple University Press.

Gupta, S. K. (2000). Sanctum for the War Criminal: Extradition Law and the International Criminal Court. California Criminal Law Review, 3, 1-35.

Harriott, A. (2003). Social Identities and the Escalation of Homicidal Violence in Jamaica. In A. Harriot (Ed.), Understanding Crime in Jamaica: New Challenges for Public Policy (pp. 89-112). Kingston: University of the West Indies Press.

Henley, K. (2006). Sovereignty, Augusto Pinochet, and Legal Positivism. Human Rights Review, 8, 67-77. 
http://dx.doi.org/10.1007/s12142-006-1016-5

Jamaica Observer (2010). Dudus Extradition Process to Begin. Jamaica Observer. www.jamaicaobserver.com/news/-Dudus_extradition-process-to-begin_7624063

Johnson, H. N., \& Soeters, J. L. (2008). Jamaican Dons, Italian Godfathers and the Chances of a "Reversible Destiny”. Political Studies, 56, 166-191. http://dx.doi.org/10.1111/j.1467-9248.2007.00682.x

Jones, M. J. (2002). Policy Paradox: Implications of US Drug Control Policy for Jamaica. Annals of the American Academy of Political and Social Science, 582, 7-19. http://dx.doi.org/10.1177/0002716202582001009

Keddie, S. A. L. (2006). Outsourcing Justice: A Judge's Responsibility When Sending Parties to Mediation. Penn State International Law Review, 25, 717-736.

Lee, R. (1988). Dimensions of the South American Cocaine Industry. Journal of Inter-American Studies and World Affairs, 30, 87-103. http://dx.doi.org/10.2307/165981

Laflin, M. M. (2000). Kidnapped Terrorists: Bringing International Criminals to Justice through Irregular Rendition and Other Quasi-Legal Options. Journal of Legislation, 26, 315-336.

Mauer, M. (2005). Walter C. Reckless Memorial Lecture: Thinking about Prison and Its Impact in the Twenty-First Century. Ohio State Journal of Criminal Law, 2, 607-618.

McConville, M. (2000). A Global War on Drugs: Why the United States Should Support the Prosecution of Drug Traffickers in the International Criminal Court. American Criminal Law Review, 37, 75-102.

McPherson, B. F. (1998). Building an International Criminal Court for the 21st Century. Connecticut Journal of International Law, 13, 1-60.

Mulvey, E. (2009). Manhattan US Attorney Charges Jamaica-Based Drug Kingpin with Narcotics and Firearms Trafficking Crimes. http://www.justice.gov/dea/pubs/states/newsrel/2009/nyc082809.html

Nadelmann, E. A. (1993). Cops across Borders: The Internationalization of US Criminal Law Enforcement. University Park, PA: Penn State Press.

Nicholson, A. J. (2007). Extradition-Whose Fault Is It? Kingston: Ministry of Justice. http://www.moj.gov.jm/extraditionpressstatement

Office of Foreign Assets Control (1995). An Overview of the Foreign Narcotics Kingpin Designation Act (21 U.S.C. 1901-1908, 8 U.S.C. 1182) and Executive Order 12978 of October 21, 1995. Washington DC: US Department of the Treasury.

Padgett, T. (2009). On the Bloody Border: Mexico’s Drug Wars. Time. http://content.time.com/time/magazine/article/0,9171,1893512,00.html

Quigley, J. (2009). The United States' Withdrawal from International Court of Justice Jurisdiction in Consular Cases: Reasons and Consequences. Duke Journal of Comparative \& International Law, 19, 263-305.

Rasmussen, D. W., \& Benson, B. L. (1994). The Economic Anatomy of a Drug War: Criminal Justice in the Commons. Lanham, MD: Roman \& Littlefield.

Reiman, J. (2007). The Rich Get Richer and the Poor Get Prison: Ideology, Class, and Criminal Justice (8th ed.). Boston, MA: Pearson.

Roig-Franzia, M. (2007). US Officials Laud Transfer of Mexican Drug Suspects: Attorney General Calls Friday’s Extraditions 'Unprecedented.' Washington Post, A15.

Rowe, D. P. (2009). Are American Citizens Safe in Jamaica? The Sunday Herald. http://www.constitution-and-rights.com/support-files/are-american-citizens-safe-jamaica.pdf

Ryan, K. F. (1998). Clinging to Failure: The Rise and Continued Life of US Drug Policy. Law and Society, 32, $221-242$. http://dx.doi.org/10.2307/827753

Sheptycki, J. W. (1996). Law Enforcement, Justice and Democracy in the Transnational Arena: Reflections on the War on Drugs. International Journal of the Sociology of Law, 24, 61-75.

Sives, A. (2002). Changing Patrons, from Politician to Drug Don: Clientelism in Downtown Kingston, Jamaica. Latin American Perspectives, 29, 66-89. http://dx.doi.org/10.1177/0094582X0202900505

Spector, J. S. (1998). Extraditing Mexican Nationals in the Fight against International Narcotics Crimes. University of Michigan Journal of Law Reform, 31, 1007-1037.

Suddath, C. (2009). The War on Drugs. Time. http://www.time.com/time/world/article/0,8599,1887488,00.html?iid=sphere-inline-sidebar

Swain, J. (2004). No "Presumption of Innocence” for "90". The Nassau Guardian. http://www.bahamasb2b.com/news/wmview.php?ArtID=3527 
United Nations (1988). United Nations Convention against Illicit Traffic in Narcotic Drugs and Psychotropic Substances. Vienna: United Nations.

US Department of State (1998). International Narcotics Control Strategy Report. www.state.gov/www/global/narcotics_law/1998_narc_report/carib98.html

US Department of State (2003). International Narcotics Control Strategy Report. http://www.state.gov/j/inl/rls/nrcrpt/2003/vol1/index.htm

US Department of State (2005). International Narcotics Control Strategy Report. http://www.state.gov/documents/organization/42881.pdf

US Department of State (2007). International Narcotics Control Strategy Report. http://www.state.gov/documents/organization/81446.pdf

US Department of State (2010). International Narcotics Control Strategy Report. www.state.gov/documents/organization/137411.pdf

Williams, C. (2007). Consequences of the War on Drugs for Transit Countries: The Jamaican Experience. Crime \& Justice International, 23, 31-38.

Williams, L. (2004). Jamaica, US and Extradition. Jamaica Gleaner. http://www.jamaica-gleaner.com/gleaner/20040408/news/news1.html

Youngers, C. A. (2004). The Collateral Damage of the US War on Drugs: Conclusions and Recommendations. In C. Youngers, \& E. Rosin (Eds.), Drugs and Democracy in Latin America: The Impact of US Policy (pp. 339-366). Boulder, CO: Lynne Rienner.

Zaid, M. S. (1997). Military Might versus Sovereign Right: The Kidnapping of Dr. Humberto Alvarez-Machain and the Resulting Fallout. Houston Journal of International Law, 19, 829-843. 